Tinjauan Pustaka

\title{
Hemoprotein dalam Tubuh Manusia
}

Husnil Kadri

\section{Abstrak}

Hemoprotein adalah protein dengan kandungan hem yang terdapat hampir dalam semua sel manusia, hewan, dan pigmen fotosintesis tumbuhan. Ada berbagai macam hemoprotein yang tersebar luas dalam tubuh manusia, seperti hemoglobin, myoglobin, citoglobin, neuroglobin, dan lain-lain. Semua hemoprotein tersebut memiliki fungsi beragam yang penting untuk berlangsungnya proses metabolisme dalam tubuh. Struktur hem pada pigmen fotosintesis (klorofil) tumbuhan sama dengan hemoglobin pada manusia, tetapi ion logam pada klorofil adalah magnesium $(\mathrm{Mg})$ sedangkan pada hemoglobin adalah besi $(\mathrm{Fe})$. Perbedaan inilah yang kurang diketahui oleh sebagian masyarakat sehingga ada yang mengira mengkonsumsi klorofil tumbuhan dapat meningkatkan kadar hemoglobin darah. Oleh karena itu, artikel ini bertujuan untuk mengetahui perbedaan antara hemoprotein manusia dengan klorofil dan fungsi hemoprotein dalam tubuh manusia.

Berdasarkan bentuk ion Fe pada gugus hemnya, maka hemoprotein dapat dibagi atas: (1) Hemoprotein yang memiliki ion $\mathrm{Fe}^{2+}$ sehingga mampu mengikat oksigen yaitu; hemoglobin, myoglobin, neuroglobin, dan cytoglobin. (2) Hemoprotein yang memiliki ion $\mathrm{Fe}^{3+}$ sehingga berperan sebagai enzim oksidoreduktase yaitu; Sitokrom P450, Sitokrom yang terlibat dalam fosforilasi oksidatif, katalase, triptopan pirolase, dan NO sintase.

Kata kunci: hemoprotein, ion $\mathrm{Fe}^{2+}$, ion $\mathrm{Fe}^{3+}$

\section{Abstract}

Hemoproteins are proteins containing heme that widely distributed in humans, animals, and photosynthetic pigment of plants. There are many kind of hemoproteins in human body, such as hemoglobin, myoglobin, cytoglobin, neuroglobin, etc. Hemoproteins have the varied functions to keep normal metabolism in the body. Photosynthetic pigment of plants (chlorophyll) and human's hemoglobin have the same structure but the metal ions are different. Chlorophyll has magnesium and human's hemoglobin has iron $(F e)$. Not many people knew this difference, so some people thought if consume chlorophyll will increase blood hemoglobin level. Because of that reason, the objective of this article was to determine the difference between human's hemoprotein and chlorophyll, and the functions of hemoproteins in the human body.

Base on Fe ion state in heme group, hemoproteins are divided into: (1) Hemoproteins have ion $\mathrm{Fe}^{2+}$ state that can bind oxygen, such as hemoglobin, myoglobin, neuroglobin, and cytoglobin. (2) Hemoproteins have ion $\mathrm{Fe}^{3+}$ state that act as oxidoreductase enzymes, such as cytochrome P450, cytochromes in oxidative phosphorylation, catalase, tryptophan pyrolase, and NO synthase.

Keywords: hemoproteins, ion $\mathrm{Fe}^{2+}$ state, ion $\mathrm{Fe}^{3+}$ state

Affiliasi penulis : Bagian Biokimia Fakultas Kedokteran Universitas Andalas Padang.

Korespondensi : Husnil Kadri, Bagian Biokimia Fakultas Kedokteran Universitas Andalas Padang. husnilbiokimia@yahoo.com

\section{Pendahuluan}

Hemoprotein adalah suatu protein dengan kandungan hem yang terdapat hampir dalam semua sel tubuh manusia. Kandungan hem dari hemoprotein ini juga terdapat pada hewan dan pigmen fotosintesis tumbuhan. ${ }^{1} \quad \mathrm{Hem}$ ini selanjutnya akan berikatan dengan berbagai macam protein, seperti hem yang terikat pada protein globin akan membentuk hemoglobin, yaitu suatu hemoprotein yang sudah dikenal sebagai alat transport $\mathrm{O}_{2}$ dalam eritrosit untuk dibawa ke jaringan. ${ }^{2}$

Sebenarnya masih ada hemoprotein lain yang tersebar luas dalam tubuh manusia, seperti myoglobin, citoglobin, neuroglobin, dan lain-lain. Semua hemoprotein tersebut memiliki fungsi beragam yang penting untuk berlangsungnya proses metabolisme dalam tubuh.
Struktur hem pada pigmen fotosintesis (klorofil) tumbuhan sama dengan hemoglobin pada manusia, tetapi berbeda ion logamnya. Perbedaan inilah yang kurang diketahui oleh sebagian masyarakat sehingga ada yang mengira jika mengkonsumsi klorofil tumbuhan dapat meningkatkan kadar hemoglobin darah.

Oleh karena itulah, tulisan ini bertujuan untuk mengetahui perbedaan struktur antara hemoprotein manusia dengan klorofil dan fungsi hemoprotein dalam metabolisme sel tubuh manusia.

\section{Struktur Hem}

Hem disintesis dari senyawa siklik porfirin yaitu protoporfirin IX, yaitu suatu molekul planar yang terdiri dari empat cincin pirol. ${ }^{1,3}$ Empat cincin pirol ini saling terhubung oleh jembatan metilen $(-\mathrm{HC}=)$. Setiap cincin pirol mengikat satu atom nitrogen. Hem terbentuk bila terjadi penambahan ion ferro (besi) pada protoporfirin IX. Porfirin ini disebut juga metalloporfirin karena mengikat 
satu ion logam ferro seperti yang terdapat pada sel tubuh manusia dan hewan (Gambar 1), tetapi pada tumbuhan hanya mengikat satu ion magnesium. ${ }^{1}$

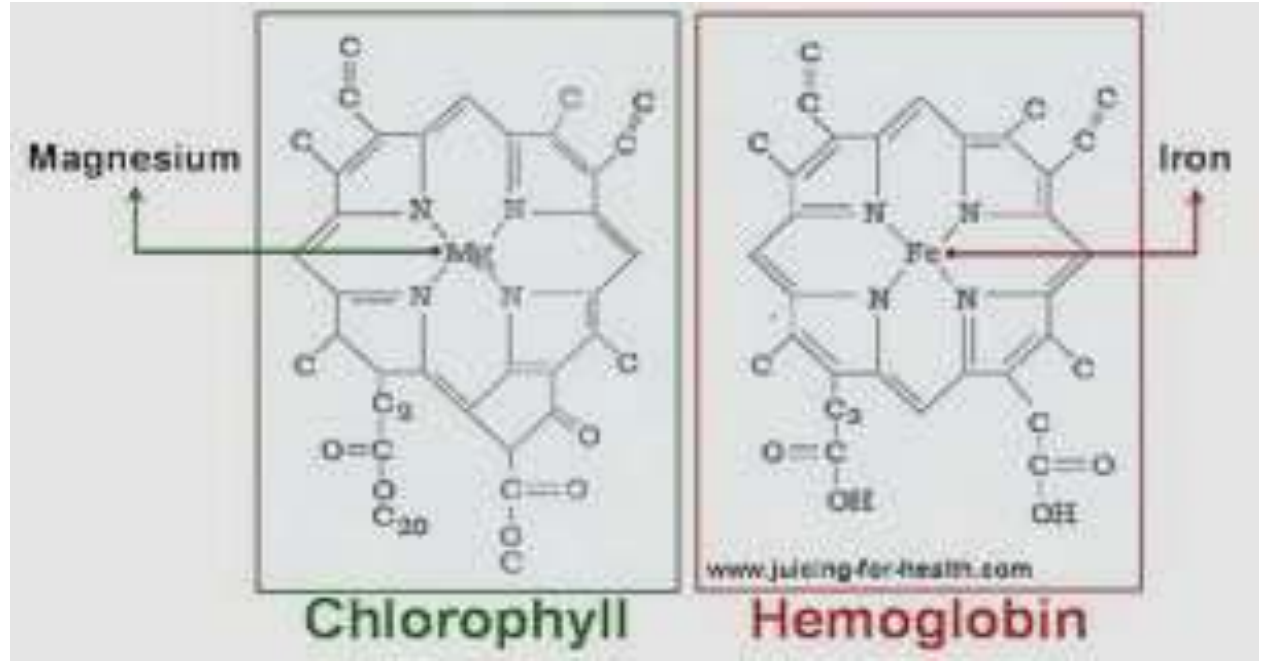

Gambar 1. Struktur Hem pada Klorofil Tumbuhan dan Hemoglobin (www.juicing-for-health.com.2011)

\section{Sintesis Hem}

Sumber hem dapat berasal dari makanan produk hewani dan hasil biosintesis sel tubuh sendiri. Pencernaan hem terjadi di lambung dan usus halus dengan bantuan protease saluran cerna. Mula-mula hem dibebaskan terlebih dahulu dari struktur proteinnya, kemudian hem yang mengandung besi diabsorpsi $25-35 \%$ oleh enterosit usus halus, sedangkan hem non besi hanya diabsorpsi $2-20 \%$ saja. $^{5}$

Hasil biosintesis sel tubuh sendiri sekitar $85 \%$ terjadi dalam sel prekursor eritrosit pada sumsum tulang dan sebagian besar sisanya dalam hepatosit. ${ }^{1}$ Biosintesis hem terdiri dari delapan tahap enzimatik yang terjadi empat tahap di mitokondria dan empat tahap juga di sitosol. Tahap enzimatik pertama dan tiga terakhir terjadi di mitokondria, sedangkan tahap dua sampai lima terjadi di sitosol. ${ }^{3}$

Material pertama yang dipelukan adalah suksinil KoA yang berasal dari siklus Kreb's dan asam amino glisin. Piridoksal fosfat (vitamin piridoksin) diperlukan untuk mengaktifkan glisin. Hasil kondensasi suksinil KoA dan glisin adalah asam $\alpha$-amino- $\beta$-ketoadipat yang dengan cepat didekarboksilasi oleh ALA sintase (Aminolevulinat sintase) menjadi $\delta$-aminolevulinat (ALA). Dua molekul ALA pindah ke sitosol untuk dikatalisis oleh ALA dehidratase menjadi porfobilinogen., ${ }^{1,3}$ Untuk lebih jelasnya, gambar tahap-tahap biosintesis hemoglobin dibawah ini dapat menerangkan bagaimana hem disintesis (Gambar 2). Perubahan protoporfirinogen III menjadi protoporfirin IX adalah satu-satunya proses oksidasi porfirin yang normal terjadi dalam tubuh. Tahap akhir biosintesis hem ialah penggabungan ion ferro kedalam protoporfirin yang dikatalisis oleh ferrokelatase (hem-sintase). ${ }^{1,3}$

Pengaturan biosintesis hem terjadi melalui kerja enzim ALA sintase. Enzim ini terdapat sebagai ALAS 1 di hepar dan ALAS 2 di sel-sel prekursor eritrosit, tetapi hanya ALAS 1 yang berperan dalam pengaturan biosintesis hem. Sintesis ALAS 1 akan meningkat bila terjadi kekurangan hem intrasel. Keadaan ini juga bisa disebabkan oleh peningkatan penggunaan hem untuk membentuk hemoprotein sitokrom P450 yang berperan dalam metabolisme obat-obatan. ${ }^{1}$

\section{Hemoprotein Yang Terdapat Dalam Tubuh Manusia}

Topik berikut ini akan memaparkan peranan beberapa hemoprotein penting yang berperan dalam mengatur metabolisme tubuh

\section{HEMOGLOBIN}

Hemoglobin adalah molekul hem dalam sel eritrosit yang mengandung hampir duapertiga kebutuhan besi tubuh. Sebuah sel eritrosit dapat mengangkut sekitar 250 juta molekul hemoglobin. Satu molekul hemoglobin terdiri dari empat ion ferro untuk empat hem yang dimilikinya. ${ }^{5}$

Bentuk hemoglobin utama pada manusia adalah $\mathrm{HbA}_{1}$, yang mana rantai globinnya terdiri dari dua rantai $\alpha$ dan dua rantai $\beta$ ( $\alpha 2 \beta 2$ ). Polipeptida $\alpha$ mempunyai 141 asam amino dan $\beta$ mempunyai 146 asam amino. Hemoglobin lain ialah $\mathrm{HbA}_{2}$ yang hanya ada sekitar $2 \%$ dari populasi. $\mathrm{HbA}_{2}$ mengandung $\alpha 2$ $\delta 2$. Darah janin mempunyai $\mathrm{Hb}$ berbeda dari orang dewasa yaitu $\mathrm{HbF}$ yang globinnya terdiri dari $\alpha 2$ ү2. ${ }^{7}$

Selain hemoglobin diatas, terdapat juga istilah untuk gangguan genetik akibat mutasi gen pada satu atau lebih urutan asam amino yang membentuk rantai globin yang disebut hemoglobinopati dan hemoglobin variant. Menurut situs HbVar (http://globin.bx.psu.edu/hbvar), sampai Oktober 2006 telah terdata sebanyak 1273 bentuk mutasi $\mathrm{Hb}$ dan talasemia. ${ }^{8}$

Fungsi utama hemoglobin ialah mentranspor $\mathrm{O}_{2}$ dari paruparu ke berbagai jaringan dan membawa $\mathrm{CO}_{2}$ serta proton $\left(\mathrm{H}^{+}\right)$dari jaringan ke paru-paru. ${ }^{2,7}$ Sebuah 
hemoglobin mengikat satu molekul $\mathrm{O}_{2}$ untuk tiap hem, jadi satu molekul hemoglobin dapat mengikat empat molekul $\mathrm{O}_{2}$, tetapi hanya satu molekul $\mathrm{CO}_{2}$ yang terikat pada rantai polipeptida globin sebagai karbamat hemoglobin (kadarnya $15 \%$ dari $\mathrm{CO}_{2}$ darah vena). ${ }^{2}$ Walaupun begitu, tidak terjadi kompetisi antar kedua gas tersebut. ${ }^{9}$
Normalnya, besi hem tereduksi sebagai ion ferro saja yang mampu mengikat $\mathrm{O}_{2}$. Jika besi hem teroksidasi, maka enzim methemo-globin reduktase akan mereduksi ferri kembali menjadi ferro. ${ }^{2}$ Hemoglobin juga mengikat vaso-dilator nitrit oksida (NO) dan inhibitor agregasi platelet. $^{7}$

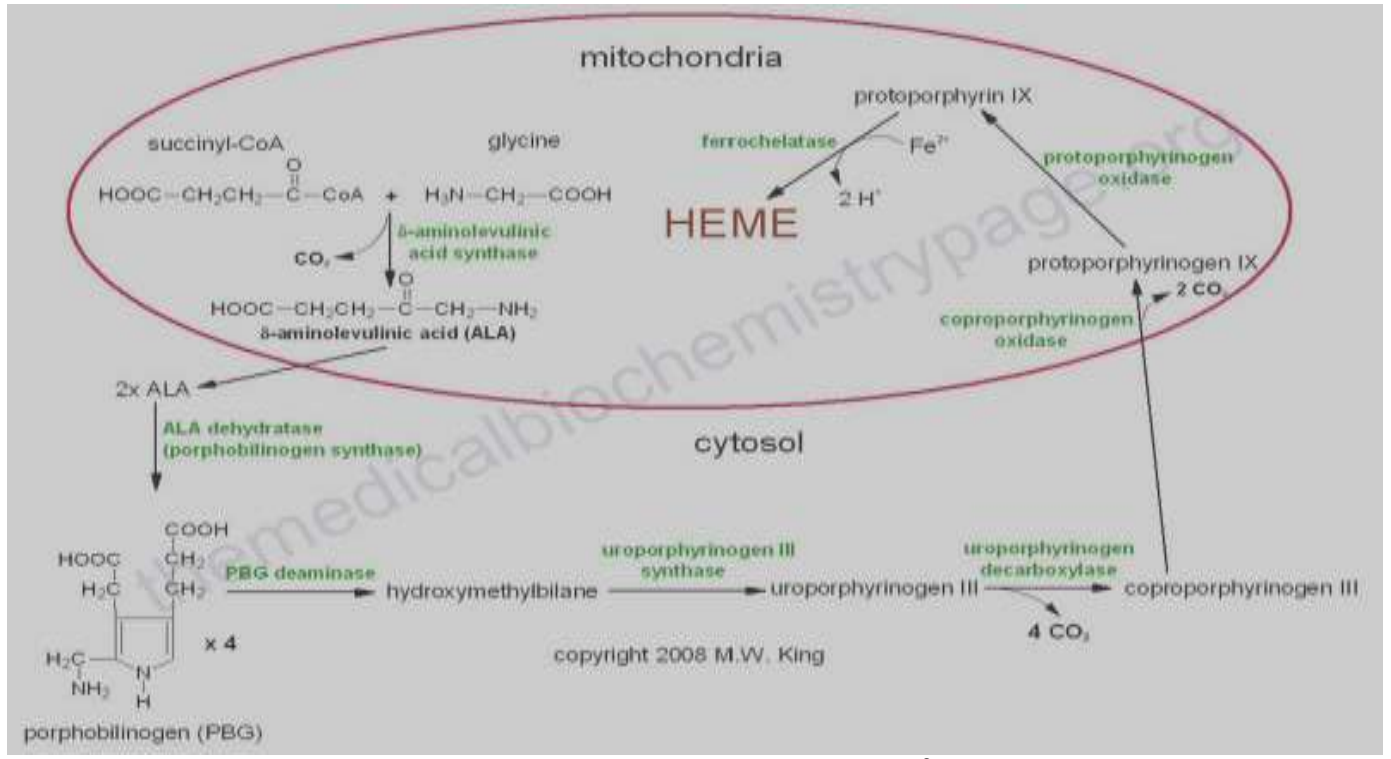

Gambar 2. Tahap-tahap biosintesis hemoglobin(copyright 2008 M.W. King) ${ }^{6}$

\section{MYOGLOBIN}

Hem pada myoglobin mengandung ion ferro seperti yang terdapat pada hemoglobin. Apabila ion ferro teroksidasi menjadi ferri, maka myoglobin juga akan kehilangan aktifitas biologisnya. ${ }^{2}$ Myoglobin berbeda dari hemoglobin karena hemoprotein sitoplasma ini hanya mengandung sebuah rantai polipeptida globin dengan 154 asam amino. Hemoprotein ini terutama terdapat pada sel myosit otot jantung dan serat otot rangka oksidatif. ${ }^{10}$

Fungsi myoglobin adalah sebagai penyimpan $\mathrm{O}_{2}$ pada sel otot, kemudian melepaskan $\mathrm{O}_{2}$ tersebut ke mitokondria untuk sintesis ATP pada saat

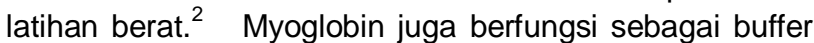
intrasellular konsentrasi $\mathrm{O}_{2}$, tujuannya agar konsentrasi $\mathrm{O}_{2}$ tetap konstan meskipun aktifitas otot sangat meningkat. ${ }^{11}$ Fungsi lainnya ialah mengikat vasodilator $\mathrm{NO}$, karena NO mempunyai kemampuan menginhibisi sitokrom $c$ oksidase yang berpotensi merusak sistem respirasi mitokondria pada otot rangka dan jantung. ${ }^{12}$

\section{NEUROGLOBIN}

Neuroglobin adalah hemopro-tein yang berhasil diidentifikasi oleh Thorsten Burmester dan kawan-kawan pada tahun 2000. Hemoprotein ini terdapat terutama dalam sistem saraf (kecuali sel glia), retina, dan beberapa jaringan endokrin (adenohipofisis, adrenal, testis). ${ }^{13}$ Rantai globinnya mirip dengan myoglobin, tetapi jumlah asam aminonya berbeda (neuroglobin = 151 aa, myoglobin $\quad=\quad 154 \quad$ aa). ${ }^{14}$

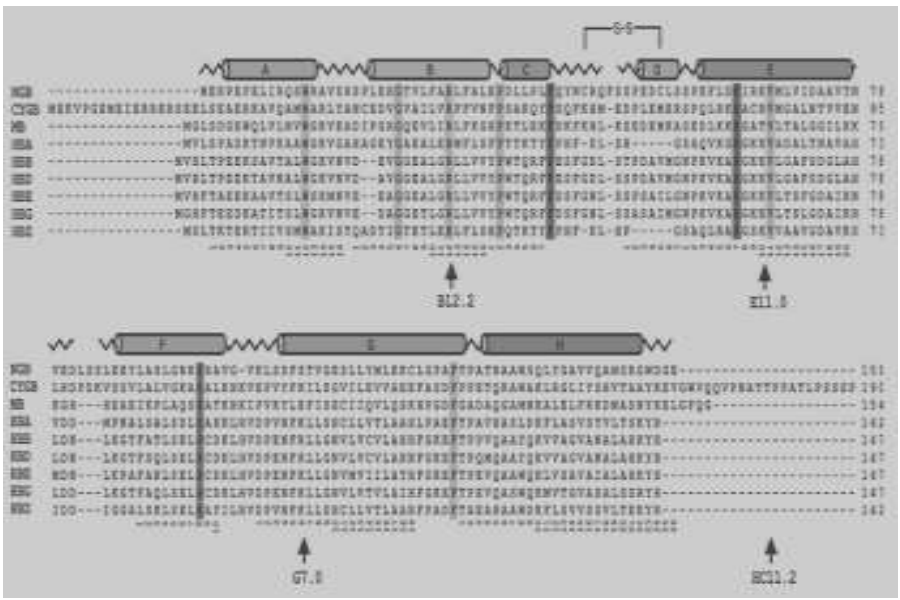

Gambar 3. Urutan Asam Amino pada Globin Manusia (Burmester et al,2002) ${ }^{15}$ $\mathrm{NGB}=$ Neuroglobin, $\mathrm{CYGB}=$ Cytoglobin, $\mathrm{MB}=$ Myoglobin, $\mathrm{Hb}=$ Hemoglobin 
Penelitian yang telah dilaku-kan tentang fungsi neuroglobin masih sangat sedikit, sehingga hasil dari suatu penelitian sering bertolakbelakang dengan penelitian lainnya. Walaupun begitu, fungsi neuroglobin mungkin adalah sebagai berikut; ${ }^{16}$

A. Sebagai neuronal myoglobin yang menyediakan $\mathrm{O}_{2}$ ke rantai respirasi.
B. Sebagai oksidase yang menyediakan $\mathrm{NAD}^{+}$ ke glikolisis anaerob.

C. Detoksifikasi reactive oxygen species (ROS) pada kondisi hipoksia.

D. Detoksifikasi nitrit oksida (NO).

E. Sebagai sensor $\mathrm{O}_{2}$.

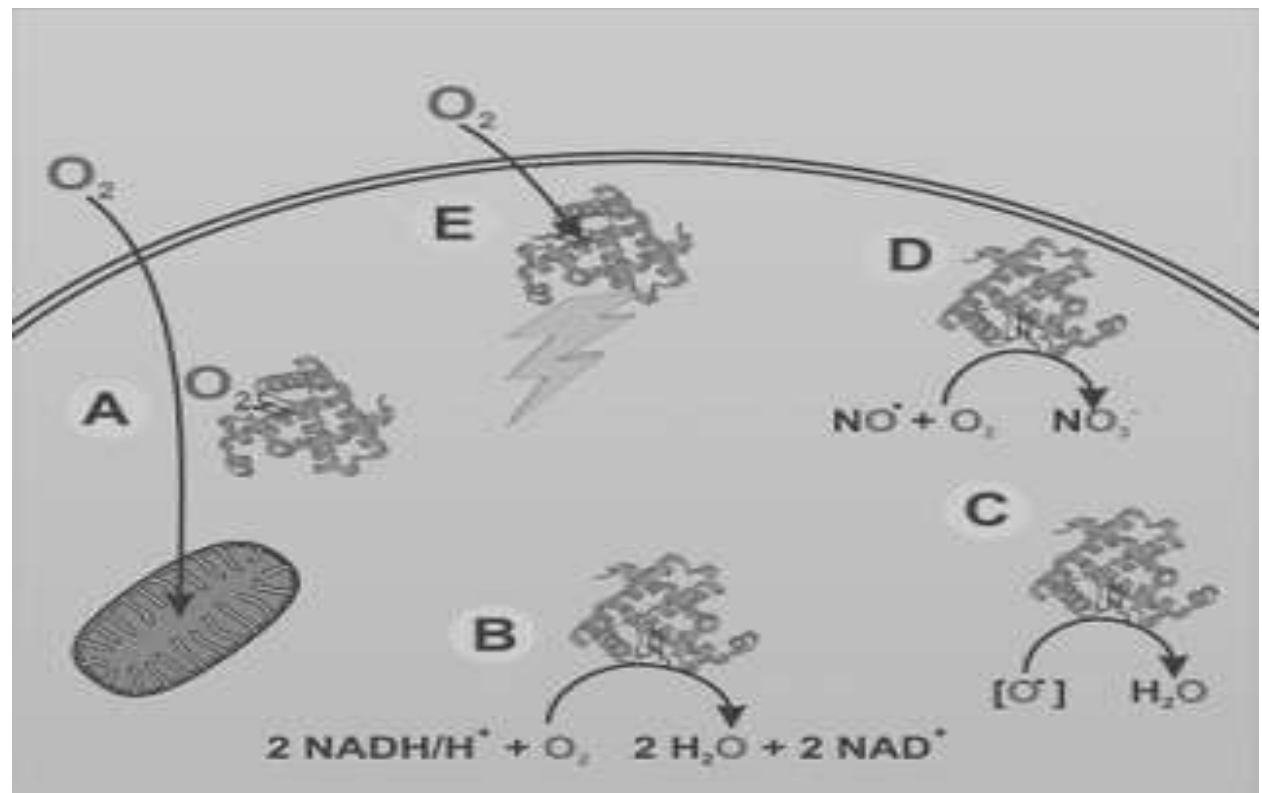

Gambar 4. Fungsi Neuroglobin (Burmester et al,2004) ${ }^{16}$

\section{Cytoglobin}

Hemoprotein ini juga dipopulerkan oleh Thorsten Burmester dan kawan-kawan pada tahun $2002 .^{15}$ Strukturnya juga hampir mirip myoglobin dan neuroglobin, tetapi cytoglobin terdapat dalam berbagai jaringan seperti jaringan penyambung, fibroblast, dan neuron, ${ }^{17,18}$ sedangkan rantai globinnya mengandung 190 asam amino. $^{19}$

Penelitian yang telah dilakukan tentang fungsi cytoglobin juga masih sangat sedikit, kemungkinan terdapat persamaan fungsi dengan neuroglobin, Fungsi cytoglobin kemungkinan adalah sebagai;

- Neuronal myoglobin yang menyediakan $\mathrm{O}_{2} \mathrm{ke}$ rantai respirasi. $^{15}$

- Oksidase yang menyediakan $N^{-} D^{+}$ke glikolisis anaerob. $^{15}$

- Sensor $\mathrm{O}_{2}{ }^{15}$

- Sintesis kolagen. ${ }^{17}$

- $\quad$ Gen supresor tumor. ${ }^{20}$

\section{Sitokrom P450}

Adalah suatu enzim monooksigenase (oksigenase) yang merupakan anggota dari kelompok enzim oksidoreduktase.
Monooksigenase ini mengkatalisis pemasukkan satu atom $\mathrm{O}$ dari molekul $\mathrm{O}_{2}$ kedalam substrat $(\mathrm{R})$ sedangkan atom $\mathrm{O}$ lainnya direduksi menjadi air. ${ }^{21}$

Sitokrom P450 berperan penting sebagai katalisator hidroksilasi pada Fase 1 dalam metabolisme xenobiotik (obat, karsinogen, pestisida, dan lain-lain) dan senyawa endogen (steroid, eikosanoid, asam lemak, dan lain-lain). Tujuan hidroksilasi adalah merubah substrat lipofilik menjadi hidrofilik agar bisa dikonjugasi dengan molekul (seperti asam glukuronat, sulfat, dan lain-lain) pada Fase 2 metabolisme xenobiotik. ${ }^{22}$

22

$$
\mathrm{RH}+\mathrm{O}_{2}+\mathrm{NADPH}+\mathrm{H}^{+} \rightarrow \mathrm{R}-\mathrm{OH}+\mathrm{H}_{2} \mathrm{O}+\mathrm{NADP}
$$

Dinamakan sitokrom P450 (cytochrome P450) karena cyto menunjukkan lokasi dan chromes berarti karakteristrik spektrofotometrik. $^{23}$ Enzim ini mengandung sebuah hem dengan spektrum absorbansi warna tertentu ( $\mathrm{P}=$ Pigmen). Angka 450 bermula dari suatu pemeriksaan spektroskopi terhadap mikrosom sel hepar tikus pada tahun 1958. Fraksi mikrosom tersebut direduksi dengan dithionite yang dilanjutkan dengan $\mathrm{CO}$ (CO akan terikat pada hem ferro), sehingga menghasilkan absorbansi paling jelas pada panjang gelombang 450 $\mathrm{nm} .^{24}$ 


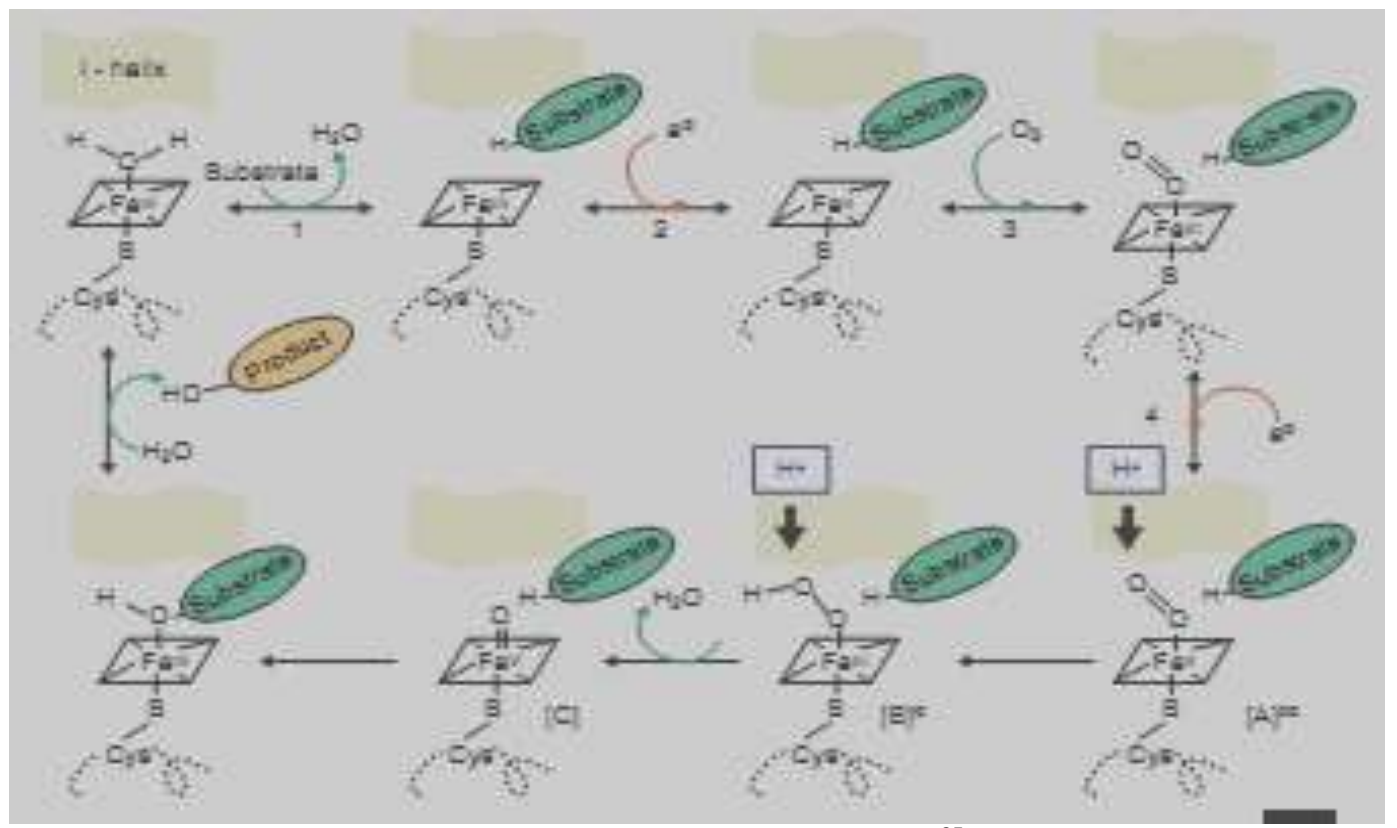

Gambar 5. Mekanisme Kerja Sitokrom P450 (Reichhart et al,2000) ${ }^{25}$

Ada berbagai macam isoform yang terdapat pada makhluk hidup, oleh karena itu diperlukan suatu pengaturan tatanama untuk membedakan berbagai isoform-isoform tersebut, dimana sitokrom P450 disimbolkan sebagai CYP, misalnya CYP1A1 berarti suatu sitokrom P450 yang merupakan anggota family 1 , subfamily A, dan anggota pertama dari subfamily tersebut. $^{22}$ Isoform-isoform tersebut merupakan protein yang terikat pada membran reticulum endoplasma dan membran dalam mitokondria. Manusia mempunyai 18 famili dan 44 subfamili gen sitokrom P450. ${ }^{24}$

\section{Sitokrom yang Terlibat dalam Fosforilasi Oksidatif}

Energi dari hasil oksidasi bahan bakar diubah menjadi ikatan fosfat berenergi tinggi (ATP=Adenosin Trifosfat) melalui proses fosforilasi oksidatif yang berlangsung pada rantai transport elektron di membran dalam mitokondria. Hasil oksidasi bahan bakar tersebut disimpan dalam bentuk koenzim penerima elektron tereduksi, $\mathrm{NADH}$ dan $\mathrm{FAD}(2 \mathrm{H})$ di dalam matrik mitokondria. Rantai transport elektron akan mengoksidasi $\mathrm{NADH}$ dan $\mathrm{FAD}(2 \mathrm{H})$ serta mereduksi $\mathrm{O}_{2}$ sehingga energi dari hasil oksidasi-reduksi ini digunakan untuk fosforilasi ADP menjadi ATP oleh ATP sintase. ${ }^{26}$

Sitokrom adalah suatu protein yang mengandung struktur hem berbeda dari hemoprotein pengikat oksigen seperti hemoglobin dan lain-lain. Besi pada hemoprotein pengikat oksigen harus dalam bentuk ion Ferro $\left(\mathrm{Fe}^{2+}\right)$ yang tereduksi, tetapi besi pada sitokrom berada dalam keadaan bergantian antara teroksidasi $\left(\mathrm{Fe}^{3+}\right)$ dan tereduksi $\left(\mathrm{Fe}^{2+}\right)$ dalam rantai transport elektron pada proses fosforilasi oksidatif di mitokondria. Sitokrom ini dibedakan lagi berdasarkan struktur hem yang diikatnya yaitu hem tipe $a, b$, dan $c$, sehingga dibagi atas sitokrom tipe $a, b$, dan $c^{27}$ Lokasi ketiga sitokrom tersebut dapat dilihat pada Gambar 6 dibawah ini. 


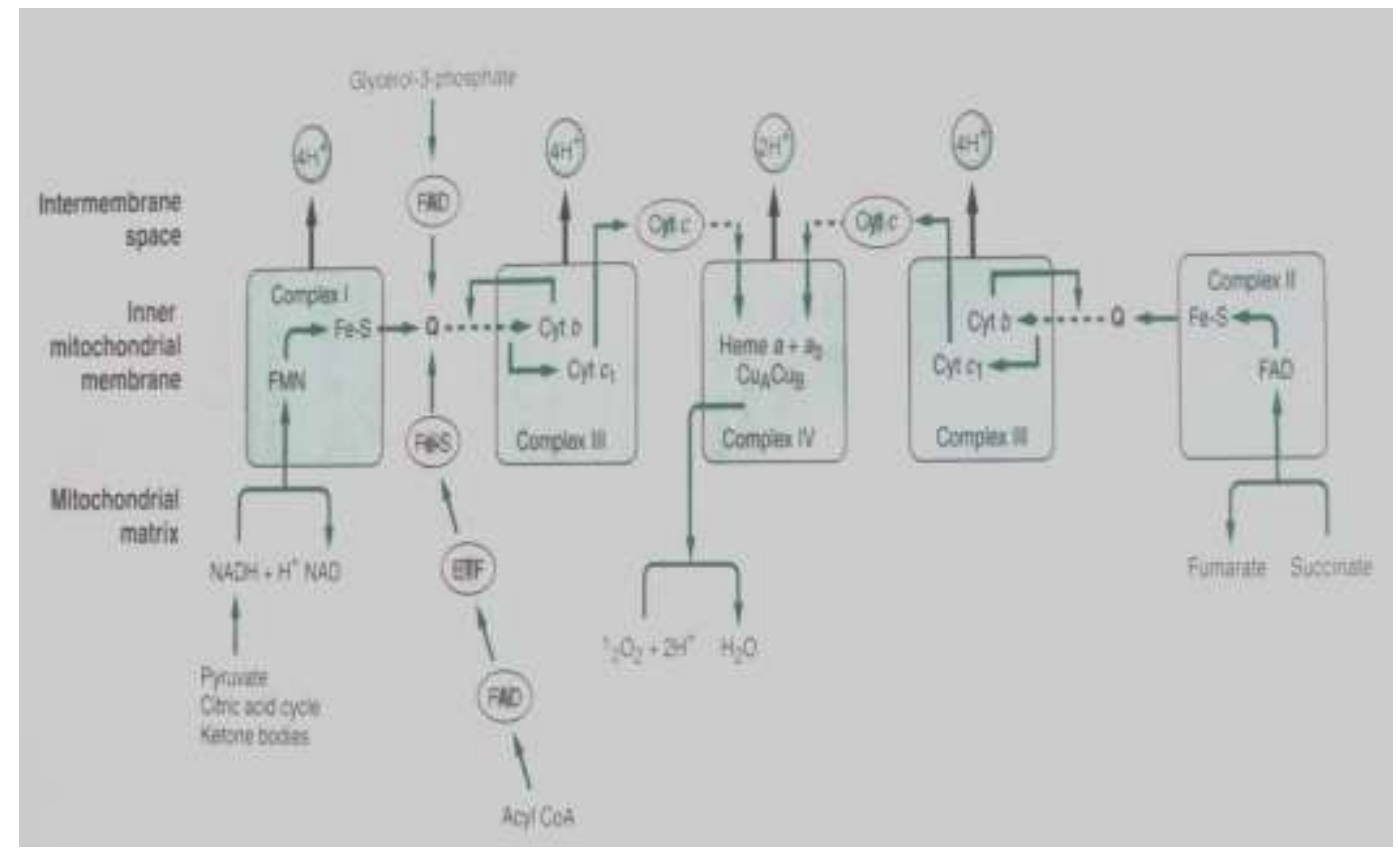

Gambar 6. Sitokrom c,b, dan a pada Rantai Transpor Elektron

(Botham et al,2006) ${ }^{28}$

Pada Gambar 6 terlihat bahwa Komplek III

Sewaktu sebuah $\mathrm{QH}_{2}$ dioksidasi mengandung sitokrom $b$ dan $c_{1}$ sehingga disebut juga Komplek Sitokrom $b c_{1}$ atau Q-sitokrom c oksidoreduktase. Komplek III mengkatalisis transfer elektron dari $Q$ (ubiquinol) ke sitokrom $c$ (di ruang intermembran) agar terjadi translokasi proton dari membran dalam mitokondria ke ruang intermembran. Proses ini dinamakan Siklus $Q^{27,28}$

menjadi $Q$, maka satu elektron diberikan kepada Sitokrom c melalui Rieske Fe-S dan sitokrom $c_{1}$, sedangkan elektron kedua kepada $Q$ untuk membentuk semiquinon $(\cdot Q)$ melalui sitokrom $b \mathrm{~L}$ (low-potential) dan $b \mathrm{H}$ (highpotential). Semiquinon selanjutnya mendapatkan sebuah elektron lagi dari $\mathrm{QH}_{2}$ kedua sehingga semiquinon tersebut tereduksi menjadi $\mathrm{QH}_{2}$ dan $2 \mathrm{H}^{+}$ditarik dari matrik. ${ }^{27-28}$ Untuk lebih jelasnya dapat dilihat pada creduced $+4 \mathrm{H}^{+28}$

$\mathrm{QH}_{2}+2 \mathrm{Cyt}$ coxidazed $+2 \mathrm{H}_{\text {matrix }}^{+} \rightarrow \mathrm{Q}+2 \mathrm{Cyt}$ Gambar.7 dibawah ini.

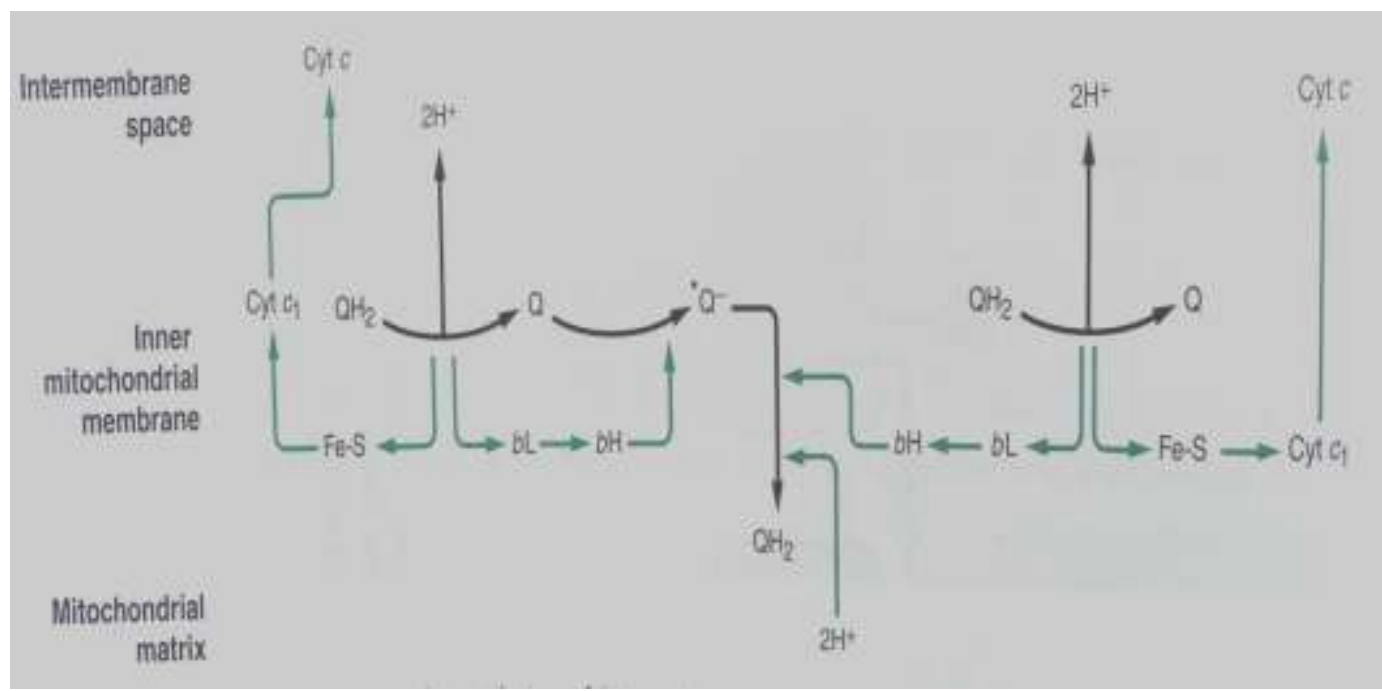

Gambar 7. Siklus Q (Botham et al,2006) ${ }^{28}$

Sitokrom $c$ tereduksi di ruang intermembran proton $\mathrm{H}^{+}$ke ruang intermembran. ${ }^{28,29}$ Lihat Gambar.6 adalah pembawa elektron ke Komplek IV yang diatas. Transfer elektron dari sitokrom $c$ tersebut, mulamengandung sitokrom $c$ oksidase. ${ }^{28}$ Enzim ini akan mula melalui $\mathrm{Cu}_{\mathrm{A}}$ kemudian berturut-turut ke hem $a$, hem mengoksidasi sitokrom $c$ bersamaan dengan tereduksinya $a_{3}, \mathrm{Cu}_{\mathrm{B}}$, dan terakhir kepada $\mathrm{O}_{2}{ }^{28} \mathrm{Hem}$ a dan $a_{3}$ $\mathrm{O}_{2}$ menjadi $\mathrm{H}_{2} \mathrm{O}$. Reaksi ini diikuti dengan pemompaan 
sebenarnya terdapat dalam satu protein yang dikenal sebagai sitokrom $a_{3}{ }^{21}$

\section{Katalase}

Peroksisom adalah organel dalam sel yang memiliki enzim-enzim dengan kemampuan menghasilkan hidrogenperoksida/ $\mathrm{H}_{2} \mathrm{O}_{2}$ (seperti oksidase) dan meredamnya (seperti katalase). ${ }^{21}$ Terdapat lebih dari 50 enzim dalam peroksisom dari jaringan berbeda. Beberapa dari enzim tersebut mengoksidasi asam amino, asam urat, dan lain-lain dengan menggunakan molekul
$\mathrm{O}_{2}$. Efek samping proses ini adalah terbentuknya $\mathrm{H}_{2} \mathrm{O}_{2}$ dalam jumlah besar. ${ }^{30}$

Katalase termasuk kelompok enzim hidroperoksidase yang terdapat dalam darah, sumsum tulang, membran mukosa, ginjal, dan hepar. ${ }^{21}$ Enzim ini mengandung empat gugus hem dan empat rantai polipeptida yang setiap rantainya terdiri dari sekitar 500 asam amino. ${ }^{31}$ Satu molekul katalase mampu meredam jutaan molekul $\mathrm{H}_{2} \mathrm{O}_{2}$ setiap detik. ${ }^{32}$ Mekanisme kerja katalase sebenarnya belum sepenuhnya dimengerti, kemungkinan terdiri dari dua tahap $;^{33}$

$$
\begin{array}{cl}
\mathrm{H}_{2} \mathrm{O}_{2}+\mathrm{Fe}(\mathrm{III})-\mathrm{E} & \rightarrow \mathrm{H}_{2} \mathrm{O}+\mathrm{O}=\mathrm{Fe}(\mathrm{IV})-\mathrm{E}(.+) \\
\mathrm{H}_{2} \mathrm{O}_{2}+\mathrm{O}=\mathrm{Fe}(\mathrm{IV})-\mathrm{E}(.+) \rightarrow \mathrm{H}_{2} \mathrm{O}+\mathrm{Fe}(\mathrm{III})-\mathrm{E}+\mathrm{O}_{2}
\end{array}
$$

$\mathrm{Fe}(\mathrm{III})-\mathrm{E}$ mewakili $\mathrm{Fe}$ dalam hem yang terikat pada enzim, sedangkan $\mathrm{O}=\mathrm{Fe}(\mathrm{IV})-\mathrm{E}(.+)$ adalah komplek yang mengandung $\mathrm{Fe}$ tidak teroksidasi sempurna, sehingga hem ini disebut juga radikal kation. Hasil akhir reaksi katalase dengan $\mathrm{H}_{2} \mathrm{O}_{2}$ ialah terbentuknya air dan oksigen. ${ }^{33}$

\section{L-Triptopan Dioksigenase}

Enzim yang terutama terdapat dalam hepar ini disebut juga triptopan pirolase, mengkatalisis reaksi penggabungan satu molekul $\mathrm{O}_{2}$ ke dalam substrat $(\mathrm{A}){ }^{21}$

$$
\mathrm{A}+\mathrm{O}_{2} \rightarrow \mathrm{AO}_{2}
$$

Triptopan pirolase berperan penting untuk mengoksidasi asam amino essensial L-triptopan menjadi $\mathrm{N}-\mathrm{L}-$ Formylkynurenine. ${ }^{34}$ Enzim ini adalah protein homotetramer yang mengandung dua atom $\mathrm{Cu}$ dan dua molekul hem. Satu molekul triptopan pirolase diperkirakan mampu mengoksidasi 1950 molekul triptopan tiap menit. ${ }^{35}$

\section{NO Sintase}

Enzim hemoprotein ini banyak terdapat dalam sitosol sel endotel otot polos. Fungsinya ialah mengkatalisis asam amino arginin menjadi sitrulin dan vasodilator NO (nitrit oksida) dengan $\mathrm{Ca}^{2+}$ sebagai aktifator. NO syntase adalah enzim yang sangat komplek karena terdiri dari lima kofaktor redoks; NADPH, FAD, FMN, hem, dan tetrahidrobiopterin. ${ }^{36}$

NO sintase terbagi atas subtype; ${ }^{36}$

1. nNOS yang terdapat dalam sel neuron sebagai aktivator calmodulin

2. iNOS yang terikat calmodulin dalam makrofag

3. eNOS yang terdapat dalam sel endotel pembuluh darah

\section{KESIMPULAN}

Terdapat berbagai macam hemoprotein dalam tubuh manusia yang bila ditinjau dari kandungan ion $\mathrm{Fe}$ pada gugus hemnya dapat dibagi atas:

1. Hemoprotein yang memiliki affinitas terhadap oksigen bila ion Fe pada hemnya tereduksi $\left(\mathrm{Fe}^{2+}\right)$ yaitu; hemoglobin, myoglobin, neuroglobin, dan cytoglobin.

2. Hemoprotein yang berperan sebagai enzim oksidoreduktase bila ion $\mathrm{Fe}$ pada hemnya teroksidasi $\left(\mathrm{Fe}^{3+}\right)$ yaitu: Sitokrom P450, Sitokrom yang terlibat dalam fosforilasi oksidatif, katalase, triptopan pirolase, NO sintase.

\section{KEPUSTAKAAN}

1. Murray RK. Porphyrins \& bile pigments. In: Murray RK, Granner DK, Rodwell WW, editors. Harper's Illustrated Biochemistry. $27^{\text {th }}$ ed. United States: The McGraw-Hill Companies, 2006: 279-93.

2. Kennelly PJ, Rodwell VW. Protein: Myoglobin \& hemoglobin. In: Murray RK, Granner DK, Rodwell VW, editors. Harper's Illustrated Biochemistry. $27^{\text {th }}$ ed. United States: The McGraw-Hill Companies, 2006: 41-8.

3. Awad WM. Iron \& heme metabolism. In: Devlin TM, editor. Textbook of Biochemistry with Clinical Correlations. $5^{\text {th }}$ ed. New York: Wiley-Liss, 2002: 1053-79.

4. www.juicing -for-health.com. Chlorophyll image. (cited 2011 June).

5. Wildman REC, Medeiros DM. Advanced human nutrition. Boca Raton London NY Washington: CRC Press; 2000.

6. King MW. Iron homeostasis. themedicalbiochemistrypage.org. 2011. (cited 2011

Desember 10): http://themedicalbiochemistrypage.org/hemeporphyrin.html

7. Schultz RM, Liebman MN. Protein II: structurefunction relationships in protein families. In: Devlin TM, editor. Textbook of Biochemistry with Clinical Correlations. $5^{\text {th }}$ ed. New York: Wiley-Liss, 2002: $367-412$ 
8. Giardine B, dkk. HbVar database of human hemoglobin variants and thalassemia mutations: 2007 update. Wiley-Liss, Inc. 2007. (cited 2011 July 01): http://globin.bx.psu.edu/hbvar

9. Linberg $\mathrm{R}$, Conover $\mathrm{CD}$, Shum KL, Shorr RG. "Haemoglobin based oxygen carriers: how much methaemoglobin is too much?". Artif Cells Blood Substit Immobil Biotechnol 26 (2).

10. Kendrew JC, Parrish RG, Marrack JR. and Orlans ES.The species specificity of myoglobin. Nature 1954; 174: 946-49. In: Ordway GA, Garry DJ. Myoglobin: an essential hemoprotein in striated muscle. The Journal of Experimental Biology 2004; 207: 3441-446.

11. Meyer RA, Sweeney HL, and Kushmerick MJ. A simple analysis of the "phosphocreatine shuttle". Am. J. Physiol. Cell Physiol 1984; 246: C365-C377. In: Ordway GA, Garry DJ. Myoglobin: an essential hemoprotein in striated muscle. The Journal of Experimental Biology 2004; 207: 3441-446.

12. Brunori, M. Nitric oxide, cytochrome-c oxidase and myoglobin.Trends Biochem Sci 2001a. 26, 21-23. In: Ordway GA, Garry DJ. Myoglobin: an essential hemoprotein in striated muscle. The Journal of Experimental Biology 2004; 207: 3441-446.

13. Reuss S, Saaler-Reinhardt S, Weich B, Wystub S, Reuss M, Burmester T, and Hankeln T. Expression analysis of neuroglobin mRNA in rodent tissues. Neuroscience 2002; 115: 645-56.

14. Burmester $T$, Weich $B$, Reinhardt $S$, and Hankeln, $T$. A vertebrate globin expressed in the brain. Nature 2000, 407,520-523. In: Pesce A, Bolognesi M, Bocedi A, Ascenzi P, Dewilde S, Moens L, Hankeln $\mathrm{T}$, and Burmester T. Neuroglobin and cytoglobin: Fresh blood for the vertebrate globin family. EMBO reports 2002; 3 (12):1146-51.

15. Burmester $T$, Ebner B, Weich B, and Hankeln $T$. Cytoglobin: a novel globin type ubiquitously expressed in vertebrate tissues, Mol. Biol. Evol 2002; 19: 416-21.

16. Burmester T, Hankeln T. Neuroglobin: A respiratory protein of the nervous system. News Physiol Sci 2004; 19: 110-13.

17. Schmidt M, Gerlach F, Avivi A, Laufs T, Wystub S, Simpson JC, Nevo E, Saaler-Reinhardt S, Reuss S, Hankeln $T$ et al. Cytoglobin is a respiratory protein in connective tissue and neurons, which is upregulated by hypoxia. J Biol Chem 2004; 279: 8063 69.

18. Nakatani K, Okuyama H, Shimahara Y, Saeki S, Kim DH, Nakajima Y, Seki S, Kawada N \& Yoshizato K. Cytoglobin / STAP, its unique localization insplanchnic fibroblast-like cells and function in organ fibrogenesis. Lab Invest 2004; 84: 91-101.

19. De Sanctis D, Dewilde S, Pesce A, Moens L, Ascenzi P,Hankel T, Burmester $T$ \& Bolognesi M. Crystal structure of cytoglobin: the fourth globin type discovered in man displays heme hexa-coordination. J Mol Biol 2004; 336: 917-27.
20. Shivapurkar N, Stastny V, Okumura N, Girard L, XieY, Prinsen C, Thunnissen FB, Wistuba II, Czerniak B, Frenkel E et al. Cytoglobin, the newest member of the globin family, functions as a tumor suppressor gene. Cancer Res 2008; 68: 7448-56.

21. Botham KM, Mayes PA. Biologic oxidation. In: Murray RK, Granner DK, Rodwell VW, editors. Harper's Illustrated Biochemistry. $27^{\text {th }}$ ed. United States: The McGraw-Hill Companies, 2006: 94-9.

22. Murray RK. Metabolism of xenobiotics. In: Murray RK, Granner DK, Rodwell WW, editors. Harper's Illustrated Biochemistry. $27^{\text {th }}$ ed. United States: The McGraw-Hill Companies, 2006: 633-640.

23. Wikipedia, the free encyclopedia. Heme. (cited 2011 Aug 16): http://en.wikipedia.org/wiki/Cytochrome $\underline{P 450}$

24. Nelson D. Cytochrome P450s in humans. Molecular Basis of Disease IV. (cited 2011 Feb 4): http://drnelson.uthsc.edu/talks/P450lect.2009.pdf

25. Reichhart DW, Feyereisen R. Cytochromes P450: a success story. Genome Biology 2000, 1(6):reviews3003.1-3003.9. (cited 2011 Mei 26): http://genomebiology.com/2000/1/6/reviews/3003

26. Marks DB, Marks AD, Smith CM. Basic medical biochemistry: a clinical approach. Dalam: B.U. Pendit, penerjemah. Biokimia Kedokteran dasar: Sebuah Pendekatan Klinis. Eds. J. Suyono., V. Sadikin., L.I. Mandera. Jakarta: EGC, 1996.

27. Beattie DS. Bioenergetics and oxidative metabolism. In: Devlin TM, editor. Textbook of Biochemistry with Clinical Correlations. $5^{\text {th }}$ ed. New York: Wiley-Liss, 2002: 536-95.

28. Botham KM, Mayes PA. The respiratory chain \& oxidative phosphorylation. In: Murray RK, Granner DK, Rodwell VW, editors. Harper's Illustrated Biochemistry. $27^{\text {th }}$ ed. United States: The McGrawHill Companies, 2006: 100-11.

29. Michel $\mathrm{H}$. The mechanism of proton pumping by cytochrome c oxidase. Proc. Natl. Acad. Sci. USA 1998; 95: 12819-24.

30. Devlin TM. Eukaryotic cell structure. In: Devlin TM, editor. Textbook of Biochemistry with Clinical Correlations. $5^{\text {th }}$ ed. New York: Wiley-Liss, 2002: 3-26.

31. Science Projects. Catalase kinetics. (cited 2011 Desember 11): http://www.scienceprojects.com/catalasekinetics.htm

32. Shanthini R. Introduction to enzymes, enzyme catalyzed reactions and simple enzyme kinetics. (cited $2011 \quad$ September 23): http://rshanthini.com/tmp/CP504/CP504Lecture 03 OK.ppt

33. Boon EM, Downs A, Marcey D. Catalase: $\mathrm{H}_{2} \mathrm{O}_{2}$ : $\mathrm{H}_{2} \mathrm{O}_{2}$ Oxidoreductase. Catalase Structural Tutorial Text. (cited 2007-02) http://biology.kenyon.edu/BMB/Chime/catalase/fram es/cattx.htm 
34. Rodwell VW. Catabolism of the carbon skeleton of amino acids. In: Murray RK, Granner DK, Rodwell VW, editors. Harper's Illustrated Biochemistry. $27^{\text {th }}$ ed. United States: The McGraw-Hill Companies, 2006: 255-69.

35. Poillon WN, Maeno $H$, Koike $K$, Feigelson $P$. "Tryptophan oxygenase of pseudomonas acidovorans. Purification, composition, and subunit structure." J Biol Chem 1969, 244(13):
3447-56. ( cited 2011 Desember 06) in: http://metacyc.org/META/NEWIMAGE?type=ENZYME-IN-RXNDISPLAY\&object $=$ CPLX-4621

36. Murray RK. Muscle \& the cytoskeleton. In: Murray RK, Granner DK, Rodwell WW, editors. Harper's Illustrated Biochemistry. $27^{\text {th }}$ ed. United States: The McGraw-Hill Companies, 2006: 565-87. 